\title{
Seed rain dynamics following disturbance exclusion in a secondary tropical dry forest in Morelos, Mexico
}

\author{
Eliane Ceccon ${ }^{1,2}$ \& Patricia Hernández ${ }^{3}$ \\ 1, 2. Correspondence Author: aCentro Regional de Investigaciones Multidisciplinarias. Universidad Nacional Autónoma \\ de México Av. Universidad s/n, Circuito 2 Colonia Chamilpa, Cuernavaca, Morelos México, 62210, phone (55) \\ 56227715, fax (777) 3175981; ececcon@miranda.ecologia.unam.mx \\ 3. Universidad Autónoma del Estado de Morelos; alis137@hotmail.com
}

Received 22-V-2008. Corrected 10-VIII-2008. Accepted 11-IX-2008.

\begin{abstract}
In most of the legally protected areas in Mexico local inhabitants use natural resources, such as fire wood or cattle grazing. These frequent but low-intensity disturbances have consequences at various levels of the tropical ecosystems and strongly impact forest structure and its regeneration capacity. Despite their importance, the effects of these perturbations in many aspects of tropical forest ecology and in the forest's capacity to recover after disturbance exclusion remain poorly understood. Understanding the impact of these processes on tropical forests is necessary for rehabilitating these forests and enhancing their productivity. In this study, we evaluate the impact of twelve years of exclusion (E) of cattle grazing and fire wood extraction in the composition and dynamics of seed rain, and compare this assessment to a similar analysis in an area where these perturbations continued (without exclusion, WE). We found a strong seasonality in seed rain ( $96 \%$ of seeds fell in the dry season) in both areas. There were no significant differences between E and WE sites in relation to overall seed density, species richness and diversity. However, the distribution along the year of seed species density was significantly different among the E and WE sites. The Jaccard's similarity index between E and WE sites was relatively low (0.57). Barochory was the most common dispersal mode observed among the 23 species in terms of seed species density (48\%), followed by anemochory (39\%) and zoochory (13\%). In relation to seed density, anemochory was the most frequent dispersal mode $(88 \%)$. Most species in the zone were categorized as small seeds $(92 \%)$, and there were no significant differences in the distribution of seed size between E and WE. The spatial pattern of dispersal of the four species with the highest relative importance value index, in both areas, was aggregated. Twelve years of disturbance exclusion were not enough to fully restore the seed rain of the area; some differences were already perceptible after this lapse. On the other hand, zoochorous species were almost absent from both sites. The re-introduction of climax and animal-dispersed species may be, in addition to perturbation exclusion, a viable strategy to accelerate ecological restoration in this area. Rev. Biol. Trop. 57 (1-2): 257-269. Epub 2009 June 30.
\end{abstract}

Key words: Archeological Zone of Xochicalco, temporal seed dynamics, spatial seed distribution, dispersal syndrome, ecological restoration.

Tropical dry forests (TDF) of Mexico have suffered drastically due to human perturbation: In 1990, the national total of forested area without anthropogenic perturbation was just $6.98 \%$ (Flores and Gerez 1994). Even in most of Mexico's legally protected areas, local people regularly also use natural resources such as fire wood and cattle grazing. The Archeological Zone of Xochicalco (AZX) in the state of
Morelos, is today a legally protected area, as well as a relatively well-preserved archeological site. Between 650-900 AD, Xochicalco was a very important, consolidated, political, religious and commercial center for the Tlahuica people and was declared a World Heritage Site by UNESCO in 1999 (UNESCO 1999). The ecosystem of the AZX has been continuously degraded due to human activities since 
ancient times. More recently (around 1930), the area suffered an intense and extensive fire. Currently, the TDF in the area is mostly composed of secondary forest. In addition, the inhabitants of the neighbouring village of Cuentepec have used the area for seasonal cattle grazing and fire wood extraction since 1987. In 1993, before the AZX was declared a World Heritage Site, a barbed wire fence was set in place to protect the archeological zone. Since then, an important area of this TDF has been free from anthropogenic perturbations, whereas the other side of the fence is still affected by cattle grazing and fire wood extraction.

Many studies have shown that in disturbed, fragmented and degraded tropical landscapes, seed availability is a major factor limiting for vegetation recovery (e.g. Duncan and Chapman 1999, Holl 1999). Therefore, spatial and temporal patterns of seed rain composition are indicators of the regenerative potential of disturbed landscapes. At the same time, knowledge of the processes occurring at seed and seedling stages is necessary for understanding the dynamics of populations and communities (e.g. Brokaw 1982, Lieberman and Lieberman 1987, Swaine et al. 1987). Seed dispersal studies are central to understanding TDF ecology, evolution and management (Wyatt-Smith 1987, Hammond et al. 1996, Schupp et al. 2002) but few studies that have examined the dynamics of seed production and seedling recruitment in TDF (Lieberman and Lieberman 1984, Bullock and Solis-Magallanes 1990, Sabogal 1992, Ceccon et al. 2002, 2003, 2004). As proposed by seminal study of Campbell et al. (1990) seed rain, and not the seed bank, direct TDF succession. Hence, seed rain dynamics is fundamental in affecting the successional processes in TDF.

Prolonged anthropogenic impact increases the importance of seed rain, since it depletes alternative sources for regeneration and may also reduce seed rain quantity and diversity, by eliminating seed dispersal agents (Howe and Miriti 2004). An understanding of the effect of human disturbances on seed rain dynamics is fundamental for the development of techniques that may improve the forest regeneration (MacMahon 1987).

The main goal of this study was to investigate the impact of a 12-year-long exclusion of cattle grazing and fire wood extraction on the restoration of seed rain composition of the exclusion area, by comparing it to a non-exclusion area during one year in a secondary TDF.

\section{MATERIALS AND METHODS}

Study site: The study was performed in the Mexican state of Morelos, in the Archeological Zone of Xochicalco (AZX; $18^{\circ}$ $22^{\prime}-19^{\circ} 07^{\prime} \mathrm{N}$, and $98^{\circ} 37^{\prime}-99^{\circ} 47^{\prime} \mathrm{W}$ ), which lies in the Tembembe river basin. The climate of the Xochicalco region is warm (Aw), with an average monthly temperature of $21^{\circ} \mathrm{C}$ and annual precipitation ranging 1000 and $1500 \mathrm{~mm}$. There is a well-defined dry season from October to May (Gómez-Garzón 2002). The average altitude is $1500 \mathrm{~m}$ and slopes range from 25 to $48 \%$. The predominant soil is Rendzina-litholic with medium texture (Gómez-Garzón 2002). The predominant vegetation is tropical deciduous forest (Miranda and Hernandez, 1963). A previous study on the structure and composition of the tree and shrub community identified 1425 individuals in 40 tree species and $(\mathrm{DBH}>3.0 \mathrm{~cm})$ per ha (Goméz-Valencia 2006). The most important species found in the area were: Bursera copalifera (Burseraceae), Pseudosmodingium perniciosum (Anacardiaceae), Bursera glabrifolia (Burseraceae), Ipomoea wolcottiana (Convolvulaceae), Alvaradoa amorphoides (Simarubaceae) and Dodonea viscosa (Sapindaceae).

Land use history of the AZX: Xochicalco was a fortified political, religious and commercial centre from the troubled period of $650-900$ AD (UNESCO 1999). Since then, the natural ecosystems of the AZX have been affected by human activities. More recently (around 1930) the zone has suffered one intense and extensive burning, and then, most of TDF in the area is 
of a secondary nature. Today we estimate (by means of informal interviews with watchmen at the AZX) that in the rainy season around 125 to 150 heads of cattle remain in the area withoutexclusion. The inhabitants of the nearby village of Cuentepec ( $3 \mathrm{~km}$ away) are regarded as the main agents causing human perturbations at the site. A recent study on fire wood used by these people, found that all families (3500 people) used fire wood for cooking and 13\% (around 450 people) of them collected fire wood from the WE slopes of AZX (area nearly $8000 \mathrm{~m}^{2}$ ). The average consumption was $1 \mathrm{Kg}$ of fire wood per day (Vazquez-Perales et al. 2005). Therefore, is possible to estimate that around 164.25 tons of fire wood is collected from the WE area of AZX per year.

Sampling techniques: In the 1993, the AZX were divided longitudinally (eight slopes) by the fence. Therefore, it is possible to compare with and without exclusion areas in the same slope. On each slope, 2 plots $(10 \times 20 \mathrm{~m})$ were located on each side of the fence at a distance of about $15 \mathrm{~m}$ from it $(30 \mathrm{~m}$ from each other). The two pairs of plots were located at the top and bottom of the slope respectively. In total, 16 plots were defined ( 8 on the E site and 8 on the WE site). Inside each plot, five seed traps of fine-mesh nylon (with $0.05 \mathrm{~mm}$ of aperture) were randomly located, suspended from a $60 \times 60 \times 60 \mathrm{~cm}$ steel frame. The traps hung from steel poles of about $1 \mathrm{~m}$ of height that stood in insecticide-soaked foam to hinder access of seed harvesters. Traps were emptied at monthly intervals, beginning on March 2004 and ending on March 2005. Trap contents were taken into the laboratory and sorted by hand. All viable seeds ( $>1.5 \mathrm{~mm}$ diameter) of trees and shrubs were extracted and identified (Foster 1985). Species and dispersal syndrome were determined by comparison to the seed collections of the HUMO herbarium in CEAMISH (Centro de Educación Ambiental e Investigación Sierra de Huautla) and the Botanical Laboratory of Biological Sciences of Autonomous University of Morelos State. Additionally, up to 30 seeds of each species per site (E and WE) were counted and weighed to estimate seed mass. Spatial and temporal seed rain dynamics were analyzed independently for the four species with the highest relative importance value index (RIVI).

Data analysis: A two sample KolmogorovSmirnov test was used to compare species richness, density and diversity along with the effect of exclusion of perturbation.

The relative importance value index of species and Shannon Species Diversity Index (S') were calculated separately for E and WE sites. The similarity seed rain species compositions between the two sites (E and WE) were evaluated through the Jaccard's index.

A correlation analysis (Pearson) was used to test the relationship between community seed fall patterns and precipitation for each site (E and WE; CNA 2004-2005). A KolmogorovSmirnov test was used to compare the effect of exclusion of perturbation in the monthly distribution of seed fall and to compare the effect of exclusion of perturbation in the density of each species; a goodness-of-fit model was employed $\left(\chi^{2}\right)$. The spatial seed distribution for the four most important species was calculated using a negative binomial distribution (k parameter).

Seeds were categorized by weight $(\mathrm{mg})$ in three levels: small (0.0005-0.030), medium (0.031-0.080) and large (>0.081). In order to compare the distribution of seeds in each weight category by dispersal syndrome between $\mathrm{E}$ and WE sites, a goodness-of-fit model was used $\left(\chi^{2}\right)$. Finally, average seed weight of the four most important species in $\mathrm{E}$ and WE sites were compared using a non-parametric two-sample Kolmogorov-Smirnof test.

\section{RESULTS}

Seed density: A total of 11511 seeds (400 seeds $\mathrm{m}^{-2}$ ) of 23 tree and shrub species distributed in 12 families were captured between April 2004 and March 2005. Fabaceae had the most species ( 7 species) followed by the Burseraceae (4 species). Anacardiaceae presented the 
highest seed density (119 seeds.m ${ }^{-2}$ ), and was composed by Pseudoesmodigium perniciosum species. In the other extreme, Ficus petiolaris and Bursera fagariodes $\left(0.03\right.$ seeds $\mathrm{m}^{-2}$; Table I) were the species with the lowest densities.

During the year, the E site showed a total of 422 seeds $\mathrm{m}^{-2}$, composed of 18 species in 9 families. The species with the highest seed density were Heliocarpus terebinthaceus ( $\cong 200$ seeds. $\mathrm{m}^{-2}$ ), Alvaradoa amorphoides $(\cong 78$ seeds. $\mathrm{m}^{-2}$ ), Pseudoesmodigium perniciosum $\left(\cong 53\right.$ seeds. $\left.\mathrm{m}^{-2}\right)$. Seeds of Ceiba aesculifolia,
Pitecoctenium equinatum, Fraxinus udhei, Acacia farnesiana and Acacia cochliacantha were absent at this site (Fig. 1).

The WE site showed a total of 378 seeds. $\mathrm{m}^{-2}$ composed by 18 species in 10 families. Species with the highest seed density were Pseudoesmodigium perniciosum $\left(\cong 185\right.$ seeds. $\left.\mathrm{m}^{-2}\right)$, Heliocarpus terebinthaceus $\left(\cong 82\right.$ seeds. $\left.\mathrm{m}^{-2}\right)$ and Alvaradoa amorphoides ( $\cong 53$ seeds.m ${ }^{-2}$ ). Acacia bilimekii, Bursera grandifolia, Thevetia thevetioides, Ficus petiolaris and Bursera fagaroides were absent at this site (Fig. 1).

TABLE I

Dispersal syndrome, seed weight, total seed density and relative importance value index (RIVI) of species at the exclusion (E) site and the site without exclusion (WE) in the seed rain of AZX

\begin{tabular}{|c|c|c|c|c|c|c|}
\hline Family & Species & $\begin{array}{c}\text { Dispersal } \\
\text { Syndrome }^{1}\end{array}$ & $\begin{array}{l}\text { Seed Weight } \\
(\mathrm{mg})^{2}\end{array}$ & $\begin{array}{c}\text { Density } \\
\left(\text { seeds. } \mathrm{m}^{-2} \text { ) }\right.\end{array}$ & $\begin{array}{c}\text { RIVI } \\
\text { E }\end{array}$ & $\begin{array}{l}\text { RIVI } \\
\text { WE }\end{array}$ \\
\hline Anacardiaceae & Pseudoesmodigium perniciosum & A & $0.010(0.000)$ & 119 & 9.34 & 30.10 \\
\hline Tiliaceae & Heliocarpus terebinthaceus & A & $0.007(0.000)$ & 112 & 29.82 & 9.55 \\
\hline Simaroubaceae & Alvaradoa amorphoides & A & $0.008(0.000)$ & 65 & 15.37 & 13.39 \\
\hline Tiliaceae & Heliocarpus velutinus & $\mathrm{A}$ & $0.015(0.001)$ & 42 & 2.34 & 11.64 \\
\hline Sapindaceae & Dodonaea viscosa & A & $0.010(0.000)$ & 19 & 5.40 & 3.85 \\
\hline Burseraceae & Bursera copallifera & $\mathrm{B}$ & $0.071(0.002)$ & 15 & 7.80 & 6.80 \\
\hline Fabaceae & Indigofera platycarpa & $\mathrm{B}$ & $0.001(0.000)$ & 6 & 6.70 & 4.98 \\
\hline Fabaceae & Leucaena leucocephala & $\mathrm{B}$ & $0.137(0.023)$ & 6 & 1.66 & 3.71 \\
\hline Fabaceae & Acacia bilimekii & $\mathrm{B}$ & $0.040(0.001)$ & 4 & 2.53 & 0 \\
\hline Fabaceae & Acaciella houghii & $\mathrm{B}$ & $0.011(0.002)$ & 3 & 3.83 & 0.80 \\
\hline Fabaceae & Lysiloma divaricada & $\mathrm{B}$ & $0.032(0.001)$ & 3 & 3.73 & 1.64 \\
\hline Burseraceae & Bursera glabrifolia & $\mathrm{B}$ & $0.043(0.002)$ & 3 & 3.40 & 4.31 \\
\hline Convolulaceae & Ipomea arborescens & $\mathrm{A}$ & $0.105(0.018)$ & 2 & 4.13 & 3.41 \\
\hline Bombacaceae & Ceiba aesculifolia & A & $0.129(0.007)$ & 0.65 & 0 & 0.97 \\
\hline Anacardiaceae & Spondias purpurea & $\mathrm{A}$ & $0.001(0.001)$ & 0.20 & 0.80 & 0.81 \\
\hline Burseraceae & Bursera grandifolia & $\mathrm{B}$ & $0.189(0.015)$ & 0.17 & 0.81 & 0 \\
\hline Apocynaceae & Thevetia thevetioides & $\mathrm{Z}$ & $0.102(0.006)$ & 0.06 & 0.79 & 0 \\
\hline Bignoniaceae & Pitecoctenium equinatum & A & $0.001(0.001)$ & 0.06 & 0 & 0.81 \\
\hline Fabaceae & Acacia cochliacantha & $\mathrm{B} / \mathrm{Z}$ & $0.032(0.007)$ & 0.06 & 0 & 0.81 \\
\hline Fabaceae & Acacia farnesiana & $\mathrm{B} / \mathrm{Z}$ & $0.075(0.006)$ & 0.06 & 0 & 0.81 \\
\hline Oleaceae & Fraxinus udhei & A & $0.002(0.002)$ & 0.06 & 0 & 1.61 \\
\hline Burseraceae & Bursera fagaroides & $\mathrm{B} / \mathrm{Z}$ & $0.0199(0.000)$ & 0.03 & 0.78 & 0 \\
\hline Moraceae & Ficus petiolaris & $\mathrm{Z}$ & $0.6578(0.000)$ & 0.03 & 0.78 & 0 \\
\hline
\end{tabular}

1. $\mathbf{A}=$ anemochory, $\mathbf{Z}=$ zoochory and $\mathbf{B}=$ barochory.

2. Numbers in the parentheses indicate $1 \pm$ standard error.

Data obtained from monthly observations from April 2004 through March 2005. 


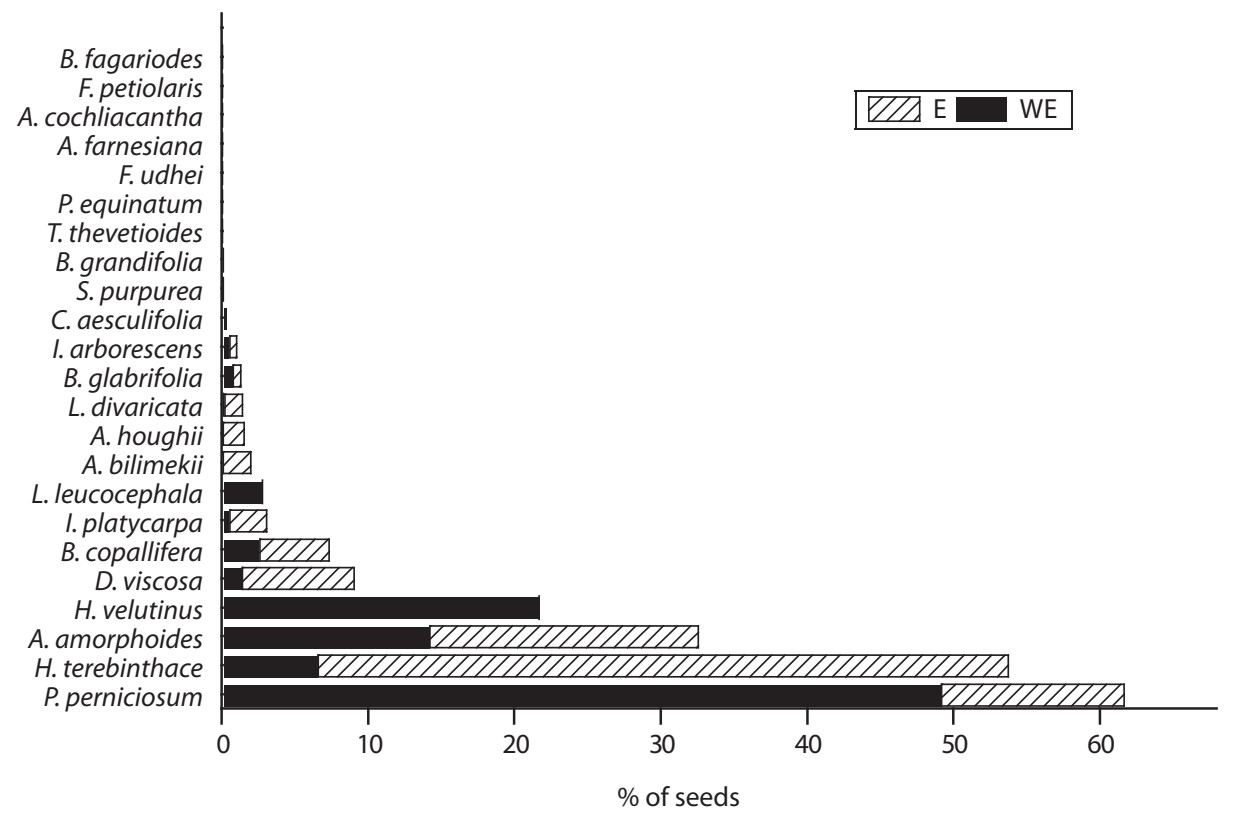

Fig. 1. Percentage of seeds by species in the seed rain in sites with exclusion (E) and without exclusion (WE) of perturbation between April 2004 and March 2005 in the AZX, in Morelos, México.

There were no significant differences in seed density between $\mathrm{E}\left(421.88 . \mathrm{m}^{-2}\right)$ and WE (377. 50 seeds. $\mathrm{m}^{-2}$; K-S, $\mathrm{p}>0.05$ ) sites. However, the density distribution of each species between the $\mathrm{E}$ and WE sites along the year was significantly different $\left(\chi^{2}=195.66, p=0.00\right.$; Fig. 1).

Temporal seed density dynamics: Around $96 \%$ of seeds were captured during the driest 6 months (between December and May). April

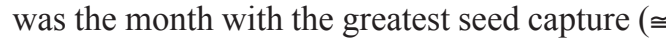
131seeds. $\mathrm{m}^{-2}$ ) and October was the month with the lowest seed capture $\left(0,17\right.$ seeds. $\mathrm{m}^{-2}$; Fig. 2 ). Seed density and precipitation showed a linear negative correlation $(\mathrm{R}=-0.75, \mathrm{p}<0.01)$. The monthly distribution of seed rain during the year was different between $\mathrm{E}$ and WE sites (K-S, P.>0.05). However, both E and WE sites were characterized by a negative correlation between seed density and precipitation $(\mathrm{R}=$ -0.65 and $\mathrm{R}=-0.75$ respectively, $\mathrm{p}<0.05)$. At the E site the month with the highest seed density was April (156 seeds), whereas in October there were no seeds at all. At the WE site, the highest seed production was observed in March (126 seeds) whereas in July there were no seeds (Fig. 2).

Species richness and diversity: Both $\mathrm{E}$ and WE sites showed the same species richness (18 species). In terms of species presence or absence, the similarity index between $\mathrm{E}$ and WE sites was 0.56 . Bottom plots of $E$ and WE sites presented the highest similarity index (0.65), while top plots of E and WE sites had the lowest similarity index (0.50).

The overall Shannon Diversity Index across site was 1.85 for the zone, and there were no significant differences between $\mathrm{E}(\mathrm{S}$ '= 1.66) and $\mathrm{WE}\left(\mathrm{S}^{\prime}=1.51\right)$ sites $(\mathrm{K}-\mathrm{S}, \mathrm{p}>0.05)$.

Dispersal Syndrome: Barochory was the most common dispersal mode observed among 


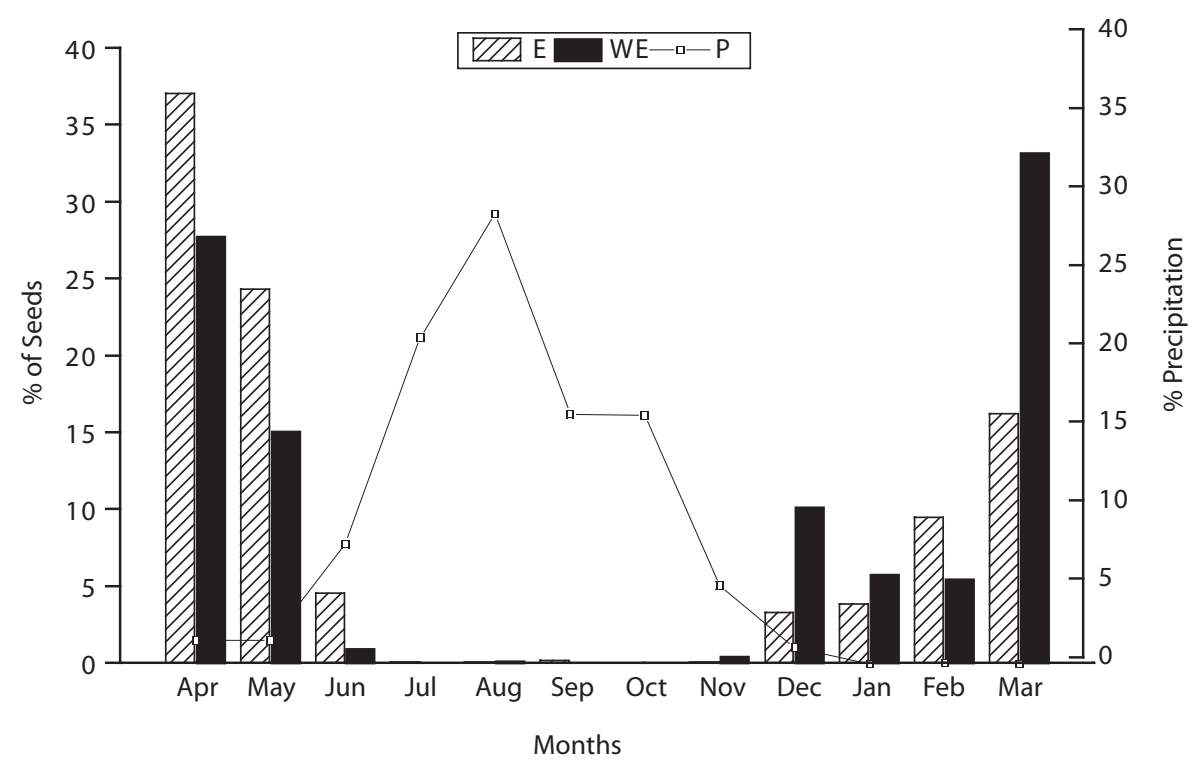

Fig. 2. Monthly percentage of seed rain with exclusion (E) and without exclusion (WE) of perturbation and percentage of annual precipitation (P) between April 2004 and March 2005 in the AZX, in Morelos, México.

the 23 species (48\% of species), followed by anemochory (39\%) and zoochory (13.08\%). However, just 3 of the 8 most important species were barochorous, while the others were anemochorous. In the exclusion area, $50 \%$ of species were barochorous, $33 \%$ anemochorous and just $17 \%$ zoochorous. In the area without exclusion, $39 \%$ of species were barochorous $50 \%$ anemochorous, and $11 \%$ zoochorous (Fig. 3).

In relation to seed density, anemochory was the most common dispersal mode $(87 \%)$, followed by barochory (13\%) and zoochory $(0.1 \%$; Table I). In the E site, $86.65 \%$ of seeds were anemochorous, $13.23 \%$ barochorous and only $0.11 \%$ zoochorous. In the WE site, $93.50 \%$ were anemochorous, $6.42 \%$ barochorous and $0.1 \%$ zoochorous (Fig. 3). There were no significant difference $\left(\chi^{2}=2.63, p=0.27\right)$ in the distribution of number of seeds by dispersal syndromes between and $\mathrm{E}$ and WE sites (Fig. 3).

Seed mass: The highest percentage of seed rain species in $\mathrm{E}$ and $\mathrm{WE}$ sites were small seeds (57.10\% and $58.28 \%$ respectively). There were no significant differences in the distribution of seed mass categories between $\mathrm{E}$ and WE sites $\left(\chi^{2}=4.34, \mathrm{p}=0.11\right)$.

Regarding seed density, the highest percentage of seed rain both at $\mathrm{E}$ and WE sites, was made up of small seeds $(90.28 \%$ y $93.17 \%$ respectively). The highest percentage of anemochorous species was categorized as small seeds (99.22\%), barochorous species were mostly categorized as medium $(61.75 \%)$ and small-sized $(24.02 \%)$, while zoochorous species presented the highest percentages of small (54.54\%) and large seeds (27.27\%).

Analysis of the highest RIVI species: Heliocarpus terebinthaceus (RIVI=20.25) presented small seeds $(0.007 \mathrm{mg}$; Table I), anemochorous dispersal syndrome and we sampled 3223 seeds during the year. Its spatially distribution was aggregated $(\mathrm{K}=0.09)$ with most seeds falling in the E site $(70.57 \%$ of seeds fell at the bottom of slopes), whereas only $4.8 \%$ of its seeds fell in the WE site. The highest seed production of $H$. terebinthaceus took 


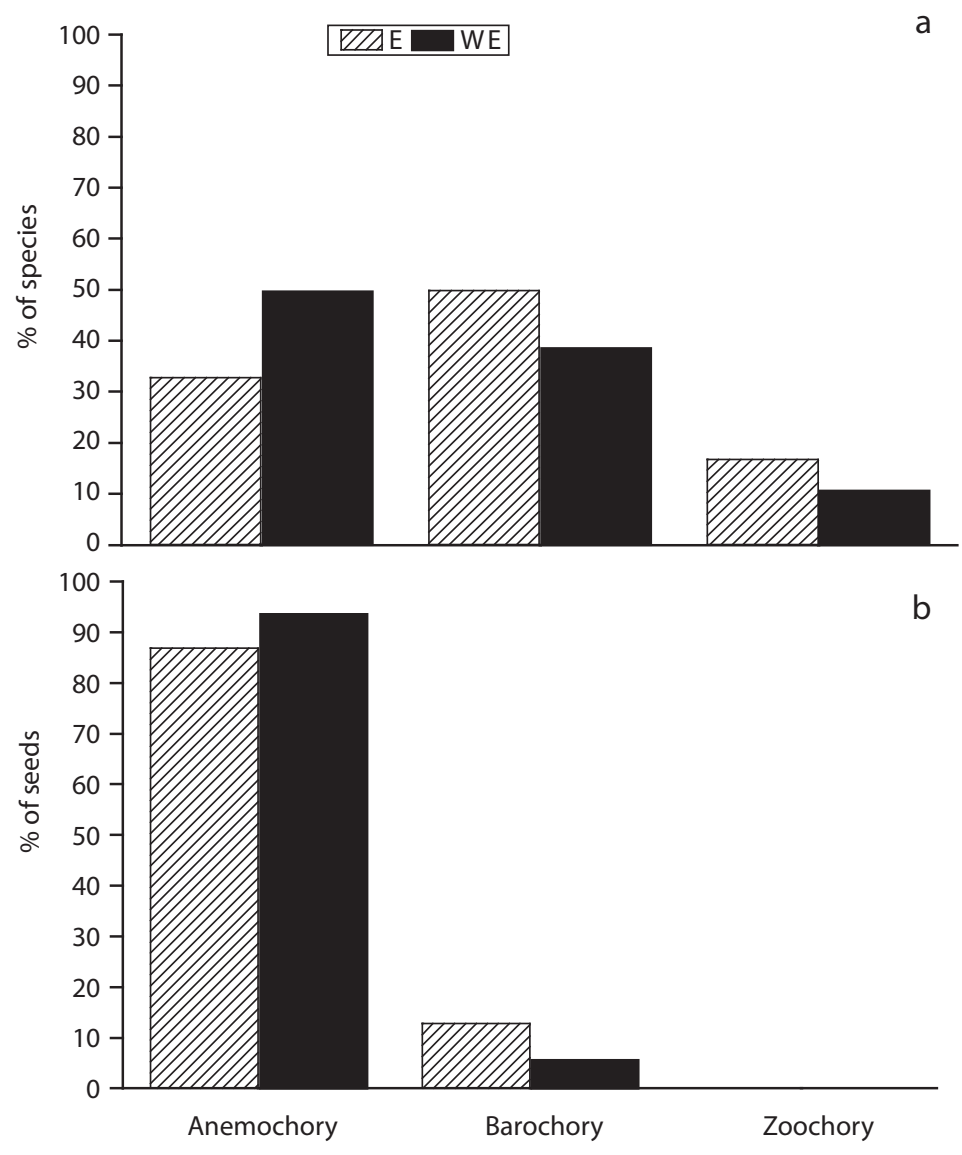

Fig. 3. Dispersal syndrome percentage of seed rain by number of species (a) and number of seeds (b) in sites with exclusion (E) and without exclusion (WE) of perturbation between April 2004 and March 2005 in the AZX, in Morelos, México.

place in April (55.81\%), while in September and November no seeds were produced (Fig. 4). There were no significant differences in seed weight between $\mathrm{E}$ and WE sites (K-S, $\mathrm{p}>0.05$ ).

Pseudoesmodigium perniciosum seeds (RIVI=19.20) were characterized as small (0.010 $\mathrm{mg}$; Table I), anemochorous dispersal syndrome and were produced at a rate of 3430 seeds per year during the study. Their pattern of spatial distribution was aggregated $(\mathrm{K}=0.18)$, and the highest number of seeds fell in the top of the slopes, mainly in WE site (77.2\%; Fig. 4). The largest seed production was observed in May (52.04\%), while in August and October there were no seeds (Fig. 4). Seeds in WE site were significantly heavier than in E site $(\mathrm{p}<0.05)$.

The seeds of Alvaradoa amorphoides $(\mathrm{RIVI}=14.44)$ dispersed by anemochory, were of small size $(0.008 \mathrm{mg}$; Table I), and were abundant (at 1885 seeds per year). In terms of spatial distribution, these seeds were aggregated $(\mathrm{K}=0.18)$ and presented no differences in density between $\mathrm{E}$ and WE sites (49.9 and $40.1 \%$ of seeds respectively; Table I). Most of the seed production took place in May $(43.02 \%)$, while from September to October there was no seed production at all (Fig. 4). Seed weight were similar in both $\mathrm{E}$ and WE sites (K-S, $\mathrm{p}>0.05)$. 


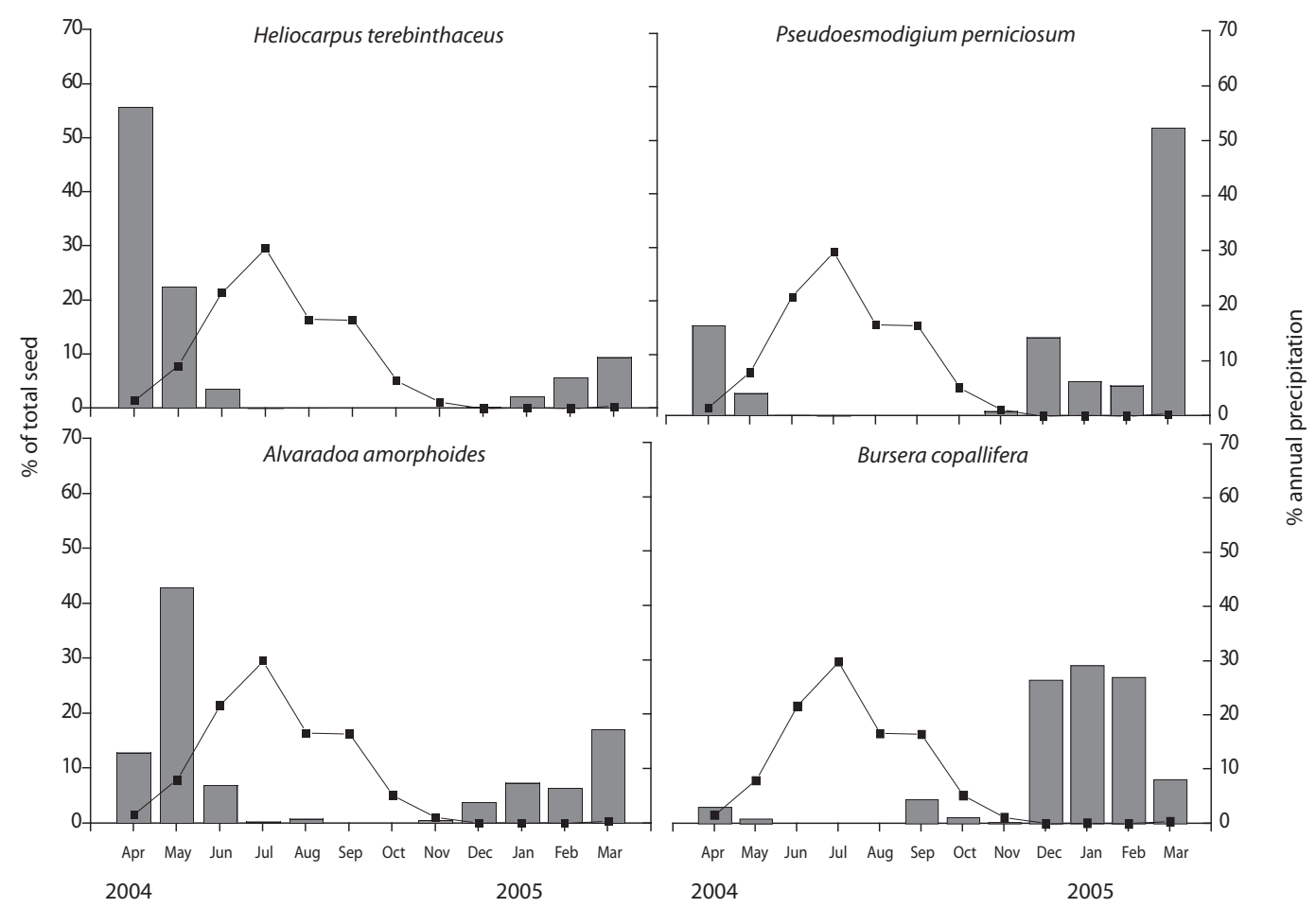

Fig 4. Monthly percentage of the total number of seeds of four species with the highest RIVI composing the seed rain (dashed lines) correlated with monthly precipitation (close bars) between April 2004 and March 2005 in the AZX, in Morelos, México.

Bursera copallifera was one of the four most important seed species (RIVI=7.33) and dispersed its medium sized seeds $(0.071 \mathrm{mg}$; Table I) through barochory. Its seed production was of 429 seeds per year and spatially aggregated $(\mathrm{K}=0.03)$. Around $69 \%$ of seeds fell in E site (79.3\% in slope 4$)$; while $31 \%$ of seeds fell in WE site (68\% fell in slope 1$)$. The most productive month was January $(28.9 \%)$, while in June and August there were no seeds (Fig. 4). There were no significant differences between $\mathrm{E}$ and WE regarding weight and volume (K-S, $\mathrm{p}>0.05)$.

\section{DISCUSSION}

Annual seed density was found to be higher in this study relative two similar studies of primary TDF (semi-deciduous) for

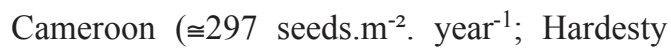
and Parker 2002) and the southeast of Brazil $\left(\cong 442\right.$ seeds.m ${ }^{-2}$. year ${ }^{-1}$; Grombone-Guaratini and Rodrigues 2002). The higher number of seeds found in this study reflect that secondary species produce many more seeds than primary species (Gomez-Pompa and Vázquez-Yanez 1974, Opler et al. 1980). Another possible explanation is the large number of small-sized, wind-dispersed species found in the area, which are known to produce many seeds (Moles and Westoby 2006).

On the other hand, species richness in the AZX (23 species) was notably lower than values reported afore-mentioned studies (Cameroon, 200 species and Brazil, 54 species). The lower species richness when compared to other mature tropical dry forests, was caused by the constant human disturbances that this zone has suffered for centuries and the last 
strong perturbation (fire) that took place around seventh years ago. These disturbances may have reduced the number of seed producing species in the area. Even if the 12 years of exclusion did not have a strong impact in the restoration of seed density, species richness or diversity, it was possible to find important differences. $\mathrm{E}$ and WE sites shared only nearly half of the species (56\%) overall. At same time, there were visible differences between $\mathrm{E}$ and WE in the most of species RIVI and in the single species density distribution. In this case, the higher soil compactness caused by the assiduous presence of cattle in the WE site (Gomez-Valencia 2006) could be affecting negatively the seed production of some species, since maternal environment affects the seed production (Fenner 1985). Thus, the visible changes in forest structure and composition observed after 12 years of exclusion in the E site by Gomez-Valencia (2006) were only beginning to be perceptible in the seed rain, mainly because many trees in this site were saplings and presented small diameters with no fully developed reproductive potential. Is well-known that trees with small diameters produce less fruits than trees with large diameters (Kelly 1994, Snook et al. 2004).

The strong seasonality of seed rain $(96 \%$ of seeds fell in the dry season) in both $\mathrm{E}$ and WE sites coincided with the results reported by Bullock and Solís-Magallanes (1990) for the tropical deciduous forest of Chamela, Mexico. Seeds are dispersed during the dry season and remain on the seed bank until the rainy season, benefiting from more favorable conditions for germination and growth. This pattern could be considered as an evolutionary response to favorable conditions (high percentage of humidity on the upper soil layer) which is present only for very short periods in the TDF (Skolung 1992, Miller 1999). The differences in monthly seed production found for $\mathrm{E}$ and WE sites in AZX may be affected by having the most abundant species in each site, producing seeds at different times (Pseudosmodingium perniciosum in the WE site and Heliocarpus terebinthaceus and Bursera copallifera in the E site; Fig. 4).
Anemochory was the dominant dispersal syndrome in both $\mathrm{E}$ and WE sites and zoochory was the least common syndrome (Fig. 3). Many studies in tropical dry forests have found a similar pattern (Barbosa et al. 1989, Viana 1990, Sabogal 1992, Machado et al. 1997, Tabarelli et al. 2003). Most of the authors cited above, relate this phenomenon to other disturbances occurring in their respective regions, where most of the vertebrates (potential seed dispersers) disappeared. The dominance of anemochorous species may be due to their high resistance to dry conditions, since they are usually present in open sites (Ericksson and Jakobsson 1999). The predominance of anemochory could also explain the strong seasonality in seed rain observed in both sites: studies carried out in the tropical dry forests of the Virgin Islands, the Caribbean Sea (Ray and Brown 1994), and Guanacaste, Costa Rica (Janzen 1967) showed that wind dispersal in these regions occurs mainly during the dry season, while that animal dispersal occurred during the rainy season. Most of these studies also found that most of the small seeds were wind dispersed as in the E and WE sites in our study. Dry fruits with small seeds of low water content are often associated with wind dispersal, and are characteristic of tropical dry forests (Bullock 1995, Griz and Machado 2001). Therefore, 12 years of exclusion from perturbation, were not enough to cause differences in dispersal mode or seed size categories relative to the without exclusion area.

In terms of spatial distribution, the four most important species in this study presented aggregated distribution. In general, seeds of tropical dry forest trees are distributed in an uneven and restricted pattern around the parental source according to the classical Hubbel (1979) study. On a seed-trap experiment on a semideciduous forest in Panama, most of the forest tree seeds were also dispersed in a temporally and spatially restricted fashion (Harms and Dalling 1997). However, Ceccon et al. (2003, 2004) found, high mortality rates in aggregated recruited tree seedlings in a TDF in Yucatan, Mexico, which suggested 
the existence of a density-dependent process caused by the aggregation of dispersed seeds.

Some authors consider the influence of the maternal environment during seed filling in TDF (Leishman et al. 2000, Khurana and Singh 2001). In this study, Pseudosmodingium perniciosum seeds were significantly heavier in the WE than in the $\mathrm{E}$ site. This species is frequently found in open sites in TDF (Guizar and Sanchez 1991, Espejo-Serna 2006) and may have well adapted to the higher light percentages present in WE site (Gomez-Valencia 2006).

Seed outputs, seed shadows and seeddispersion patterns are determined by the spatial pattern of reproductive adults (Nathan and Muller-Landau, 2000). In this study, three of the four species with highest RIVI in the seed rain (Pseudosmodingium perniciosum, Alvaradoa amorphoides and Bursera copallifera) scored high in relative importance value index as assessed in the forest structure and composition study (Gomez-Valencia 2006) and were not usually used for wood fuel by Cuentepec inhabitants. In fact, $P$. perniciosum, was regarded as poisonous by these inhabitants (Vazquez-Perales et. al, 2005). Therefore, regenerative potential of theses species in terms of seed production is assured. However, in the WE site, regeneration of these species is at risk because of the presence of cattle, since it has been demonstrated that the majority of the cattle's diet comes from browsing on seedlings, trees and shrubs (Thomas et al. 1983, Conklin 1987 in Stern 2000).

At the same time, some species that showed a low RIVI in the seed rain, showed also a low RIVI in the structure and composition study (Gomez-Valencia, 2006), possibly due to the fact that they were the most used for fire wood in Cuentepec. Indeed, the low RIVI seed species Acacia farnesiana, Leucaena leucocephala and Ficus petiolaris were used respectively by $88 \%, 75 \%$ and $48 \%$ of the families in Cuentepec (Vazquez-Perales et al. 2005). However, some species that were reported as highly important in the forest structure and composition study in the E site, were not deemed similarly important in the seed rain study (Gomez-Valencia, 2006). This may be due to the absence of cattle that allowed many more trees to establish and grow in the E site (Thomas et al. 1983, Conklin 1987) but these newly regenerated individuals possibly had not reached a reproductive age yet, and could not impact the seed rain favorably.

Therefore, it is possible to conclude that, even though cattle grazing and fire wood extraction could be considered low impact disturbances, they have significantly affected the seed rain of vegetation in the study area. Although, the 12 years of exclusion of disturbance have not been enough to fully restore seed rain of the vegetation in the area, we were already able to find some measurable positive effects. An exception to this improvement were zoochorous species, which were almost absent in both sites.

Due to the low maintenance cost of natural regeneration, this method is often considered as a good option for restoration of larger and little degraded areas (Aide et al. 2000, Hooper et al. 2005). Here, only preventing disturbance has not been enough to accelerate the restoration of the regenerative potential of zoochorous species. Therefore, the reintroduction of new climax and animal-dispersed species via manual planting of seedlings could be a desirable restoration strategy, even if more expensive. Reintroduction of seedlings of animal-dispersed species can aid propagule exchange between landscape components, given that this exchange is influenced by the presence of zoochorous tree species (Guevara et al. 1992, Ortiz-Pulido 2000 and others). Zoochorous species may also guarantee food resources to herbivores, and may sustain continuous production of fruit for dispersal, since the arrival of fauna is associated with the maintenance of seed disperser resources (Talora and Morellato 2000). Through their activity, herbivores create and modify much of the spatial heterogeneity of the vegetation that is so important to species dynamics in a community (Hunter 1992). 


\section{ACKNOWLEDGMENTS}

We thank HUMO herbarium of CEAMISH (Centro de Educación Ambiental e Investigación Sierra de Huautla) and Botanical Laboratory of Biological Sciences of University Autonomous of Morelos State for technical support, Archeological Zone of Xochicalco administration for the authorization to carry this study and to Octavio Miramontes, Angie Kitson-Harris and Natalia Mantilla for reviewing the text in English. This research was supported by grants PAPIIT- UNAM, IN231802 and IN118306.

\section{RESUMEN}

En la gran mayoría de las áreas legalmente protegidas en México, los habitantes locales utilizan los recursos naturales para leña o para la alimentación de animales. Estas perturbaciones frecuentes y de baja intensidad, impactan fuertemente la estructura y la capacidad de regeneración de los ecosistemas tropicales. A pesar de su importancia, la dinámica de la regeneración después de la exclusión de la perturbación, todavía es poco conocida. Evaluamos el impacto de doce años de exclusión (E) de la entrada del ganado y extracción de leña en la composición y dinámica de la lluvia de semillas al comparar con un área sin la exclusión de estas perturbaciones (SE). Se encontró una fuerte estacionalidad en la lluvia de semillas ( $96 \%$ de las semillas cayeron en la estación seca). No se encontraron diferencias significativas entre los sitios excluidos y no excluidos en relación a la densidad, riqueza de especies y diversidad de las semillas. Sin embargo, la distribución de estas semillas al largo del año, fue significativamente distinta entre los dos sitios. El índice de similitud entre los sitios (E y SE) fue relativamente bajo (0.57). La barocoria fue el modo de dispersión más común entre las 23 especies (48\%), seguida por la anemocoria (39\%) y la zoocoria (13\%). En lo que se refiere a la densidad de semillas, la anemocoria fue el modo de dispersión más observado $(88 \%)$. La mayoría de las especies tienen semillas pequeñas (92\%) y no se encontraron diferencias en la distribución de semillas por clases de tamaño entre los sitios E y SE. La distribución espacial de las cuatro especies más importantes fue agregada. Aunque los 12 años de exclusión no fueron suficientes para restaurar completamente el potencial regenerativo de la zona, algunas diferencias ya empezaron a ser perceptibles. Casi no hay especies zoocoras en ambos sitios y la reintroducción de especies clímax y atractoras de animales podría ser un estrategia interesante, además de la exclusión de la perturbación, para acelerar la restauración ecológica.
Palabras clave: Zona arqueológica de Xochicalco, dinámica temporal de semillas, distribución espacial de semillas, síndrome de la dispersión, restauración ecológica.

\section{REFERENCES}

Aide T.M., J.K. Zimmerman, J.B. Pascarella, L. Rivera \& H. Marcano-Vega. 2000. Forest regeneration in a chronosequence of tropical abandoned pastures: implications for restoration ecology. Rest. Ecol. 8: $328-338$.

Barbosa D.C.A., J.L. Alves, S.M. Prazeres \& A.M.A. Paiva. 1989. Dados fenológicos de10 espécies arbóreas de uma área de caatinga Alagoinha (PE). A. Bot. Bras. 3: 109-117.

Brokaw N.V.L. 1982. Treefalls: frequency, timing and consequences, p. 101-110. In Jr. E.G Leigh, A. S. Rand \& D.M. Windsor (eds.). The Ecology of a Tropical Forest: Seasonal Rhythms and Long-term Changes, Smithsonian Inst. Press, Washington, DC.

Bullock S.H. 1995. Plant reproduction in neotropical dry forests, p 277-303. In S.H. Bullock, H.A Mooney, E. Medina (eds.). Seasonally dry tropical forests, Cambridge University Press, New York.

Bullock, S.H. \& J.A. Solis-Magallanes. 1990. Phenology of canopy trees of a tropical deciduous forest in Mexico. Biotropica 22: 22-35.

Campbell B. , T. Lynam \& J.C. Hatto. 1990. Small-scale in the recruitment of forest species during succession in tropical dry forest, Mozambique. Vegetatio 87: 51-57.

Ceccon E., I. Omstead, C. Vázquez-Yanes \& J. Campo. 2002. Vegetation and soil properties in two tropical dry forests of differing regeneration status in Yucatán. Agrociencia 36: 621-631.

Ceccon E., P. Huante, J. Campo. 2003. Effects of nitrogen and phosphorus fertilization on the survival and recruitment of seedlings of dominant tree species in two abandoned tropical dry forests in Yucatán, Mexico. For. Ecol. Manag. 182: 387-402.

Ceccon, E., S. Sanchéz \& J. Campo. 2004. Tree seedling dynamics in two abandoned tropical dry forests of differing successional status in Yucatán, Mexico: a field experiment with $\mathrm{N}$ and $\mathrm{P}$ fertilization. Plant Ecol. 170: 12-26. 
Conklin N.L. 1987. The potential nutritional value to cattle of some tropical browse species from Guanacaste, Costa Rica. Ph.D. thesis, Cornell University, New York.

Duncan, R. S. \& C.A. Chapman 1999. Seed Dispersal and Potential Forest Succession in Abandoned Agriculture in Tropical Africa. Ecol. Appl. 9: 998-1008.

Espejo-Serna A. 2006. Diagnóstico de los recursos forestales no maderables y maderables no tradicionales en bosques tropicales y subtropicales en los estados de Chihuahua, Durango, Jalisco, Michoacán, Guerrero y Oaxaca. SEMARNAT. Universidad Autónoma Metropolitana-Iztapalapa México. Distrito Federal.

(also available on-line: URL: http://www.semarnat.gob. $\mathrm{mx} / \mathrm{pfnm} 2 /$ indices/indices.htm)

Fenner M. 1985. Seed Ecology. Chapman \& Hall, London, Nueva York, USA.

Flores O. \& P. Gerez. 1994. Biodiversidad y Conservación en México: Vertebrados, Vegetación y Uso de Suelo ( $2^{\text {nd }}$ edition). CONABIO, UNAM, México.

Foster S.A. 1986. On the adaptive value of large seeds for tropical moist forest trees: a review and synthesis. Bot. Rev. 52: 260-299.

Gómez-Garzón A. 2002. Caracterización del medio físico de la cuenca del río Tembembe empleando sistemas de información geográfica. Instituto Mexicano de Tecnología del Agua. Laboratorio de Sistemas de Información Geográfica del SIG CUENCAS.

Gómez-Pompa A. \& C. Vazquéz-Yanes. 1974. The life cycle of secondary species, p. 336-342. In Proceedings of the First International Congress of Ecology, The Haghe, The Netherlands.

Gomez-Valencia R. 2006. Efecto de las perturbaciones antropogénicas en la sucesión de la selva baja caducifolia de la zona de taludes de la región de Cuernavaca, Morelos. Reporte técnico. UNAM.

Griz, L.M.S. \& I.C.S. Machado. 2001. Fruiting phenology and seed dispersal syndromes in caatinga, a tropical dry forest in the Northeast of Brazil. J. Trop. Ecol. 17: 303-321.

Grombone-Guaratini M.T. \& R.R. Rodrigues. 2002. Seed bank and seed rain in a seasonal semi-deciduous forest in south-eastern Brazil. J. Trop. Ecol 18: 759774.

Guevara S. J., Meave P., Moreno-Casasola \& J. Laborde. 1992. Floristic Composition and Structure of Vegetation under Isolated Trees in Neotropical Pastures . J. Veg. Sci, 3: 655-664.
Guizar N.E. \& V.A. Sanchez. 1991. Guía para el reconocimiento de los principales árboles del Alto Balsas. Universidad Autónoma de Chapingo. Dirección de Difusión Cultural. División de Ciencias Forestales. México.

Hammond D.S., S. Gourlet-Fleury, , P. Van Der Hout H. Ter Steege \& V.K. Brown. 1996. A compilation of known Guianan timber trees and the significance of their dispersal mode, seed size and taxonomic affinity to tropical rain forest management. For. Ecol. Manag. 83: 99-116.

Hardesty B.D., V.T. Parker. 2002. Community seed rain patterns and a comparison to adult community structure in a West African Tropical Forests. Plant Ecol. 164: 49-64.

Harms K.E. \& J.W. Dalling 1997. Damage and herbivory tolerance through resprouting as an advantage of large seed size in tropical trees and lianas. J. Trop. Ecol 13: 617-621.

Holl K.D. 1999. Factors Limiting Tropical Rain Forest Regeneration in Abandoned Pasture: Seed Rain, Seed Germination, Microclimate, and Soil. Biotropica, 3 (2): $229-242$.

Hooper E., P. Legendre \& R. Condit. 2005. Barriers to forest regeneration of deforested and abandoned land in Panama. J. of Appl. Ecol. 42: 1165-1174.

Howe H. F., M.N. Miriti. 2004. When Seed Dispersal Matters. BioScience 54 (7): 651-660

Hubbell, S.P. 1979. Tree dispersion, abundance and diversity in a tropicaldeciduous forest. Science 203: 1299-1309.

Hunter M. D., T. Ohgushi, \& P. W. Price. 1992. Effects of resource distribution on animal - plant interactions. London Academic Press. England. 505 pp.

Janzen D.H. 1967. Synchronization of sexual reproduction of trees within the dry season in Central America. Evolution 21: 620-637.

Kelly, D. 1994 The evolutionary ecology of mast seeding, Trends Ecol. Evol. 9: 465-470.

Khurana E. \& J. S. Singh. 2001. Ecology of seeds and seedling growth for conservation and restoration of tropical dry forest: a review. Env. Conserv. 28: 39-52.

Leishman M.R., I.J. Wright, A.T Moles \& M. Westoby. 2000. The evolutionary ecology of seed size $\left(2^{\text {nd }}\right.$ edition), p. 31- 57. In M. Fenner (ed.). Seeds: The Ecology of Regeneration in Plant Communities . CAB International, Wallingford. 
Lieberman, D. \& M. Lieberman. 1984. The causes and consequences of synchronous flushing in a dry tropical forest. Biotropica 16: 193-201.

Macmahon J. A. 1987. Disturbed lands and ecological theory: an essay about mutualistic association, p. 231-237 In W. R. Jordan, M. E. Gilpin, \& J. D. Aber (eds.). Restoration ecology, Cambridge University Press, Cambridge, England.

Machado, I.C.S., L.M. Barros \& E. Sampaio. 1997. Phenology of caatinga species at Serra Talhada, PE, Northeastern Brazil. Biotropica 29: 57-68.

Moles A. T. \& M. Westoby. 2006. Seed size and plant strategy across the whole life cycle. Oikos 113: 91-105.

Miller P.M. 1999. Effects of deforestation on seed banks in a tropical deciduous forest of western Mexico. J. Trop. Ecol. 15:179-188

Miranda, F. \& X.E. Hernández 1963. Los tipos de vegetación de México y su clasificación. Bol. Soc. Bot. Mex. 28: 29-179.

Nathan R. \& H.C. Muller-Landau. 2000. Spatial patterns of seed dispersal, their determinants and consequences for recruitment. Trends 15: 278-285.

Opler, P.A., H.G. Beher, \& G.W. Frankie. 1980. Plant reproductive characteristics during secondary succession in Neotropical lowland forest ecosystems. Biotropica 12:40-46.

Ortiz-Pulido R. 2000. Abundance of frugivorous birds and richness of fruit resource: is there a temporal relationship? Caldasia 22:93-107

Ray G.J. \& B. J. Brown 1994. Seed Ecology of woody species in a Caribbean dry forest. Rest. Ecol. 2: 156-163.

Sabogal C. 1992. Regeneration of tropical dry forests in central America, with examples from Nicaragua. J. Veg. Sci. 3: 407-416.

Schupp, E.W., T. Milleron, \& S.E. Russo. 2002. Dissemination limitation and the origin and maintenance of species-rich tropical forests, p. 19-34. In D.J. Levey, W.R. Silva \& M. Galetti (eds.). Seed Dispersal and Frugivory: Ecology, Evolution and Conservation, CABI Publishing, New York.

Skoglund J. 1992. The role of seed banks in vegetation dynamics and restoration of dry tropical systems. J. Veg. Sci. 3: 357-360.
Snook, L. K., L. Cámara-Cabrales, J. K. Matthew. 2004. Six years of fruit production by mahogany trees (Swietenia macrophylla King): patterns of variation and implications for sustainability. For. Ecol Manag. 206: 221-235

Stern M., M. Quesada \& K. E. Stoner. 2002. Changes in composition and structure of a tropical dry forest following intermittent cattle grazing. Rev. Biol. Trop. 50: 1021-1034.

Swaine M.D., D. Lieberman \& F.E. Putz 1987. The Dynamics of Tree Populations in Tropical Forest: A Review. J. Trop. Ecol 3: 359-366.

Tabarelli M., A Vicente \& D. Barbosa, 2003. Variation of seed dispersal spectrum of woody plants across a rainfall gradient in north-eastern Brazil. J. Arid Env. 53: $197-210$.

Talora D. C. \& P. C. Morellato 2000. Fenologia de espécies arbóreas em floresta de planície litorânea do sudeste do Brasil. Rev. Bras. Bot. 23: 13-26.

Thomas D., R.P., De Andrade Couto W., C.P. Moore \& C.M.C. Da Rocha. 1983. Pasture development in the tropical savanna region of Brazil. World Rev. Anim. Prod. 19: 37-44.

Unesco 1999. World Heritage Committee Inscribes 48 New Sites on Heritage List. (also available on-line:http:// whc.unesco.org/en/news/165)

Vázquez-Perales R., J. Islas-Samperio, E. MartínezRomero, I. Toledo, E. Ceccon. 2005. Initial establishment of two Energy Plantations using agroforestry systems for small farmers: the case of the village of Cuentepec, in Mexico. 14th European Biomass Conference and Exhibition Biomass for Energy, Industry and Climate Protection. Palais des Congrès, Paris, France.

Viana V. 1990. Seed and seedling availability as a basis for management of natural forest regeneration. pp. 99-115. In Anderson, A. B. (ed.). Alternatives to deforestation: steps towards sustainable use of the Amazon rain forest, Columbia University Press, New York.

Wyatt-Smith J. 1987. Problems and prospects for natural management of tropical moist forests, p. 5-22. In F. Mergen \& J.R Vincent (eds.). Natural management of tropical moist forests. New Haven, Connecticut, Universidad de Yale. 
